\title{
Experience of sexual harassment in patients with mental disorders
}

\author{
Sukarni $^{1}$, Siti Nurjanah ${ }^{2}$ \\ ${ }^{1,2}$ Fakultas Ilmi Kesehatan, Universitas Muhammadiyah purwokerto
}

\begin{abstract}
ARTICLE INFO
Article history:

Received: August 9, 2020

Revised: August 20, 2020

Accepted: August 30, 2020

\section{Keywords:}

Sexual harrasment, mental illness

ABSTRACT

Sexual harassment is a form of an unpleasant experience making a person uncomfortable. It has physical or psychological impacts. 163-403-2-ED. The research aimed to find out the experience of sexual harassment that causes behavioral changes in patients with mental illness in Banyumas Regional Hospital.This was quantitative descriptive research. There were 32 people taken as the research sample using purposive sampling technique. The data resulted in the distribution of each variable in percentage, classified in the Slovin formula. A questionnaire from the Sexual Harassment Inventory (SHI) was also employed. The average age of the patients who had experienced sexual harassment was 31.53 years, and it happenned when they were 19.56 years. Most of them were male $(68.8 \%)$, had primary school education $(40.6 \%)$, and were already employed $(53,1 \%)$. The sexual harassment was in the form of verbal and non-verbal abuse (59.4\%). It mostly occurred $1-2 \mathrm{x}(40.6 \%)$ in patients with a history of mental care $1-3 \mathrm{x}(40.6 \%)$. The perpetrators were mostly female $(59.4 \%)$ and non-family members $(87.5 \%)$. Most of the patients experienced severe sexual harassment $(84.4 \%)$, causing annoyance (46.9\%).In conclusion sexual harassment can be a factor in mental illness.
\end{abstract}

This work is licensed under a Creative Commons Attribution 4.0 International License.

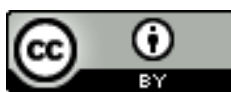

\section{Corresponding Author:}

Sukarni,

Health Faculty, Universitas Muhammadiyah Purwokerto

Email: sukami8282@gmail.com

\section{INTRODUCTION}

The Mental health is a condition in which an individual can develop physically, mentally, spiritually, and socially so that the he/she realizes his/her own ability to cope with the pressure of working productively and is able to contribute to his community. Meanwhile, people with mental disorders are those who experience disturbances in their thoughts, behavior and feelings manifested in the form of a series of symptoms and/or significant changes in behavior, and can cause suffering and obstacles in carrying out their functions as humans [1]. One of the factors to cause a disturbance of mental health is sexual harassment. It has physical and psychological impacts in research. Effective interventions or handling of sexual violence must focus on various factors, including the promotion of social support and social networks that support the victims of sexual violence from family units, organizations and communities [2].

\section{RESEARCH METHOD}

This study employed a quantitative descriptive design, with a sample of the respondents was 32 respondents, taken as total sampling. The inclusion criteria in this study were as follows: all the patients were being treated at the Integrated Mental Health Service Installation at Banyumas Hospital, male and female patients, willing to become respondents and the patients' status was maintained. This study uses a standard SHI (Sexual Harassment Inventory) instrument, good psychometric integrity, written in behavioral terms, and each behavior will be considered. This instrument was a closed questionnaires of 20 items, which can be easily adapted for use in different populations; it can be assessed to measure the severity and occurrence of sexual harassment. The responses to items 1-20 are only "yes" or "no". 


\section{RESULTS AND DISCUSSIONS}

\subsection{Characteristics of respondents}

The results showed that the average age of the respondents who experienced sexual harassment in mental patients was 31 years old, with the youngest being 18 years and the oldest being 45 years old (table 1). This is in line with Purba's (2014) finding, saying that symptoms of mental disorders often appear in the individuals in the ages of 20-40 years $(76.9 \%)$. This is the same with the age of patients who have had experiences of sexual harassment. The majority of patients were 21 years and 39 years (middle adults). Middle adulthood is one of the periods in human development [3]. It is a time of changing physical appearance due to aging. It may come with an experience of loneliness from the loss of a spouse and the marriage of their children, who then lived apart. Besides, they may have retired from their office; their income may get much less than before. It is certain that the task of development in middle adulthood is transitional [4].

\begin{tabular}{lc}
\multicolumn{2}{l}{ Table 1. Characteristics of respondent $(\mathrm{n}=32)$} \\
\hline Characteristics & Resulth \\
\hline Age $(\mathbf{y})$ & $31,53 \pm 7,870$ \\
Maean \pm SD & $18-45$ \\
Min-Max & $22(68,8 \%)$ \\
\hline Gender & $10(31,3 \%)$ \\
$\quad$ Male & \\
Female & $13(40,6 \%)$ \\
Education & $9(28,1 \%)$ \\
Primary school & $9(28,1 \%)$ \\
Secondary school & $1(3,1 \%)$ \\
Senior high school & \\
Higher education & $17(53,1 \%)$ \\
Job status & $15(46,9 \%)$ \\
Employed & Unemployed
\end{tabular}

The number of the patients with experiences of sexual harassment was dominated by male (68.8\%). According to Purba [5], both sexes have the same risk of suffering from serious mental disorders. However, the severity of mental disorders is greater in men than women, thus more men have to be hospitalized. Cordoso [6] explains the reason for this fact. Women are less at risk of suffering from mental disorders than men because they tend to be more receptive to life situations than men. Mostly the patients who had experiences of sexual harassment only had primary school education, 13 patients (40.6\%). The others had a chance to go to secondary education, junior and senior high schools, with 9 person in each, and only a patient went to college. A psychiatric dependent person cannot think normally so they usually do not finish to a higher level of education. Education is more important factor than income, and it can be used to describe mental health [7].

Education is a measure of a person's ability to interact with others effectively. Being in higher education is not a guarantee that someone is free from stress. However, the level education will have an impact on the job an individual can have. The causes of mental disorders include a precipitation factor where each individual perceives himself to be against challenges, threats, or demands for coping [8]. The higher a person's education is, the easier he/she will receive mental health information provided by health professionals. Thus, it affects him/her in making decisions about self-care efforts. The data showed that the majority of patients were employed (17 patients, 53.1\%), and other 15 (46.9\%) were unemployed. The amount of their income depends on the type of job they have. However, they can be unable to spend the income wisely, especially when their salary is not very good. They have lots of things they want, but their money is not enough. In this situation, an individual tends to easily experience despair because they cannot achieve the goals they want

\subsection{Clinical Characteristics}

The clinical characteristics include history of mental care, time of harassment, form, perpetrator's relation to patients, sex of the perpetrator, and the level of sexual harassment.

Table 4. Distribution of Clinical Characteristics $(n=32)$

\begin{tabular}{lcc}
\hline Clinical Characteristics & Frequency & Procentage \\
\hline History of mental treatment & & \\
Relapsing 1-2x & 13 & $40,6 \%$ \\
Relapsing 3-5x & 9 & $28,1 \%$ \\
Relapsing >5x & 10 & $31,3 \%$ \\
Type of harassment & & \\
\hline
\end{tabular}

Proceeding homepage: https://conferenceproceedings.ump.ac.id/index.php/pshms/issue/view/1 


\begin{tabular}{lcc} 
Verbal & 13 & $40,6 \%$ \\
Non verbal & 0 & $0 \%$ \\
$\quad$ Verbal and Non verbal & 19 & $59,4 \%$ \\
Times of harassment & & \\
1 or 2 times & 13 & $40,6 \%$ \\
3-5 times & 11 & $34,4 \%$ \\
More than 5 times & 8 & $25,0 \%$ \\
Perperators & & \\
Family & 2 & $6,3 \%$ \\
Not family / friends & 28 & $87,8 \%$ \\
Family and not family & 2 & $6,3 \%$ \\
Perperator's sex & & \\
Male & 13 & $40,6 \%$ \\
Female & 19 & $59,4 \%$ \\
Effect of harassment & & \\
Annoyed & 5 & $46,9 \%$ \\
Feared & 8 & $25,0 \%$ \\
Dissappointed & 2 & $6,3 \%$ \\
Sad & 2 & $6,3 \%$ \\
Others & 5 & $15,6 \%$ \\
Severity & & \\
Mild & 2 & $6,3 \%$ \\
Moderate & 3 & $9,4 \%$ \\
Severe & 27 & $84,4 \%$ \\
\hline
\end{tabular}

The general characteristics show that most of them have been treated more than one. They have various types of sextual harassments. The perperators are dominated by female, since the victims are male. The severity of the harassment is also various. The details of each clinical description is discussed below. For people with mental disorders, experiences of sexual abuse can have an impact on prognosis and the urgent care must be taken in dealing with complex and sophisticated needs. There is also a risk of recurrence of psychotic symptoms, considering psychological interventions to manage a history of abuse. This can lead to difficult decisions about the extent to which the problem should be addressed to provide individual psychological support for the patients with psychotic illnesses. There is some evidence that people who are sexually abused are more likely to have certain types of hallucinations (commanding hallucinations) and thoughts related to sexual harassment. In a study, Schudlich [9] found out that physical harassment is higher, namely $21 \%$ compared to other forms of harassment. The sexual harassment was significantly associated with a bad environment, more severe manic symptoms, more sub-limits of manic / hypomanic symptoms, and greater mood swings. These findings suggest that if physical / sexual abuse is reported, clinicians should note the harassment that appears to be associated with increased symptom relief, suicide, and a worse work environment. The perpetrators of sexual harassment were mostly women, 19 people $(59.4 \%)$ and and 13 perperators were male. This is related to the more male patients in the sample of respondents. This finding is different from Molhar's [10] study in a community sample that answered a mailed questionnaire, $14.2 \%$ of men and $32.3 \%$ of women reported experiencing sexual harassment (such as unwanted kissing or sexual touching by someone. The perperators were always older, 5 or more years older than them. They experienced the incidence before.

A research on sexual violence founds that, in terms of the relationship between the perpetrator and the victim, from the 16 samples of cases of sexual violence crimes, the perpetrator of the crime were the persons that the victims know, and only a case with a foreign perperators. The perperators include friends, girlfriends, neighbors, teachers, and even the victim's immediate family, like father, stepfather and grandfather [11]. Extrafamilial abuse is the one committed by other people outside the victim's family. An incest is sexual abuse done by the one having a single kinship, being part of the nuclear family. It includes a person who is a substitute for a parent, like a stepfather or lover. What victims can do to avoid the recurrance of abuse is keep away from them and to always have a companion for a protection. This includes to take a proper dressing to cover the body well.

Stated that the family, as an integral unit of society, is very important in determining how a person recovers after a traumatic event. Regardless of the level of trauma, the family is the central of all healing which can be reduced through appropriate treatment in the family [12]. Remarkable breakthroughs have been made to understand the neurobiological basis of mood and anxiety disorders, and the influence of life events on risk 
and resilience. Continuous sensitization of neural circuits is a consequence of early life stress, which is integrally involved in regulating stress and the emotions that occur in late adolescence [13].

In general, the frequent impact is feelings of annoyance, internal and external anger. The impact on the personal and social life is the victim feels humiliated, and their family relationships or socialization are very difficult to reconnect, because of the fear. The victims is hard to believe and think that sexual harassment only happens to other people, not themselves. The reality, in fact, is otherwise; they are the victimes. Then, they are afraid, feeling insecure. They always want to stay away from people or shut themselves down. This is due to the shame they have, and tend to blame themeselves. An effective interventions for sexual violence must focus on various factors, including the promotion of social support and social networks that support victims from family units, organizations, and communities [14]. The severity of post-traumatic stress disorder includes depression, suicidal ideation and drug abuse in a sample of 83 patients, nearly two thirds of the sample $(60,7 \%$,$) . Sexual harassment has been identified as a risk factor for several mental health problems during$ adolescence including depression, suicide, and low self-esteem. Ramadyan states that the level of mild sexual harassment is the light acts like staring or touching body parts. The severe one is an action of a serious nature like sexual coercion directly or indirectly by telephone or letter, raping and sexual torture [15].

\section{CONCLUSION}

Based on the anaysis, the characteristics of the mental health patients with the experience of sexual harassment are 31 years old in avaerage. Most of them are male, have a primary education, employed, and married. The perperators are mostly the family of the victims. The various impacts of the harassment include annoyance, fear, disappointment and sadness for the victims.

\section{REFERENCES}

[1] Kemenkes RI, "Undang Undang Kesehatan Jiwa Nomor18, http/www hukor.kemkesgo.id>upload>UU_No 18 2014," 2014. [Online]. [Accessed 10 Juli 2019].

[2] Merrick and Greydanus, "Incest: Child Sexual Abuse Within The Family," Int J Child Adolesc Health, vol. 10, no. 3, pp. 295-304, 2017.

[3] Wayan, "Karakteristik dan Diagnosis Psikiatri Pada Pasian Percobaan Bunuh Diri di RSUP Sanglah," E-Jurnal Medika, vol. 6, no. 10, 2017.

[4] Muzzakiyah, "Religiusitas, PenyesuaianDiri dan Subyektif Well Being Persona," Jurnal Psikologi Indonesia, vol. 5, no. 1, pp. 28-38, 2016.

[5] Purba, "Pengaruh Terapi Aktivitas Kelompok Stimulasi Persepsi Terhadap Kemampuan Pasien Mengontrol Halusinasi Di Rumah Sakit Jiwa Tampan Provinsi Riau.," Jurnal Online Mahasiswa Program StudiI lmu Keperawatan Universitas Riau 1 (1), 1-10, vol. 1, no. 1, pp. 1-10.

[6] Cordoso, Factos Associated with low quality of life in Schizofrenia, CadSaude Publica, 2015.

[7] Rosalia, "Gambaran Karakteristik Pasien Yang Mengalami Skizofrenia di RSJ Mustajab Purbalingga," Muhammadiyah Purwokerto, 2017.

[8] Kurniawan, "Gambaran Karakteristik Pada Pasien Gangguan Jiwa Skizofrenia di Instalasi Jiwa RSUD Banyumas," Universitas Muhammadiyah Purwokerto, 2016.

[9] Schudlich, Pelecehan Fisik dan Seksual dan Awal-Onset Bipolar Disorder di pemuda Rawat Jalan: sering, tapi tidak spesifik, New York: Business Media, 2014.

[10] Molhar and Berkman, "Psikopatologi, pelecehan seksual masa kanak-kanak dan kesulitan masa kanak-kanak lainnya: Hubungan relative dengan perilaku bunuh diri selanjutnya di AS," Psikol Med, vol. 31, p. 965-77, 2011.

[11] Humaira and Rohmah, "Kekerasan Seksual Pada Anak: Telaah Relasi Pelaku Korban Dan Kerentanan Pada Anak," Psikoislamika, vol. 12, no. 2, pp. 5-10, 2015.

[12] Mawarpury. and Mirza, "Resiliensi dalam Keluarga: Perspektif Psikologi," Psikoislamedia, vol. 2, no. 1, pp. 96-106., 2017.

[13] Glaser, "Pelecehan dan penelantaran anak dan otak - Tinjauan," Psikiatri Psikologi Anak, vol. 4, no. 1, pp. 97-116, 2010.

[14] Merrick and Greydanus, "Incest: Child Sexual Abuse Within The Family," Int J Child Adolesc Health, vol. 10, no. 3, pp. 295-304, 2017.

[15] Ramadyan, Pelecehan Seksual, Jakarta: Universitas Islam Negeri Syarif Hidayatullah, 2010. 